\title{
生食ならびに調理・加工用果菜類の食味に及ぼす 栽培培地と流通温度の影響
}

阿 部 一 博*

\begin{abstract}
Influence of Culture Methods and Shipping Temperature
\end{abstract}
on the Quality of Tomato and Cucumber Fruits

Kazuhiro ABE**

Summary

In this paper, the influence of culture methods (soil culture, hydroponics) on the quality of tomatoes and cucumbers was examined, and the influence of shipping temperature on the taste of tomatoes grown by hydroponics was investigated.

1) When tomatoes were grown by hydroponics using $0.4,0.7$, and 1.0 units of nutrient concentration, the taste tended to be improved with higher concentration of the solution. The taste of fruits grown with 1 unit was comparable to that of soil culture, showing almost equal levels of $\mathrm{pH}$, Brix, and titratable acidity.

2) Five cultivars of tomatoes grown with 0.7 unit of hydroponics solution were judged by taste panel as being inferior to that grown on soil.

3) Cucumber fruits grown with 2 units of hydroponic solution was inferior to that grown with 1 unit owing to the unfavorable texture.

4) The taste of tomatoes which were harvested at $30 \%$ coloring and ripened for 4 days at $20^{\circ} \mathrm{C}$ was comparable to that of fruits which were harvested at full ripe and stored for 4 days at $2{ }^{\circ} \mathrm{C}$, but was inferior to the fruits which were harvesred at full ripe and tasted on that day.

\section{緒言}

近年市場に流通している青果物の風味が低下したとい われ，その原因として，品種の変化; 耐病性や高収益を 目的とした品種改良, 肥料の変化; 有機質肥料から化学 肥料への変遷, 栽培方法の変化; 周年供給を目的とした 施設栽培の普及, 流通システムの変化; 流通システムの 複雑化ないし，流通経路の延長，などが考えられる。

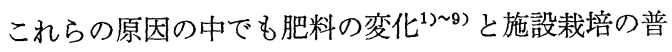

* 大阪府農林技術センター（开583羽电野市尺度 442$)$

**Osaka Prefecture Agricultural Research Institute(442

Shakudo Habikino Osaka 583 Japan)
及 ${ }^{10) \sim 12)}$ (1982年，大阪府 $\left.2,774,128 \mathrm{~m}^{2}\right)$ の影響が大きい と思われ，とくに水耕栽培 (1984年，大阪府 $126,348 \mathrm{~m}^{2}$ ) は, 栽培培地として, 化学肥料成分を含んだ水を利用す るため, 生産された青果物の品質が低いといわれること が多い。本研究では, 水耕栽培の培養液を調整すること により，高品質のトマトやキュウリを生産する方法を検 討するとともに, 水耕栽培されたトマトの食味に及ぼす 収穫熟度と流通温度の影響を調べた。

\section{1. 実験材料および方法}

(1) 実験 材料

(A) 栽培条件 : 水耕栽培ならびに土耕栽培は無加温の 


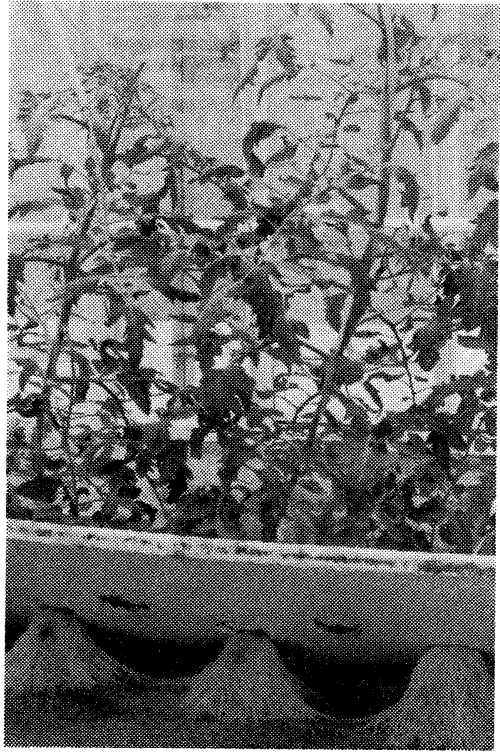

Fig. 1 Tomato growing by hydroponics

ガラス室で行い, 土耕栽培は 50 入りのポットに砂畩土 を入れ, 堆肥ならびに化学肥料を常法で施用した。水耕 栽培は $50 l$ 入染トなら゙に改良M式水耕栽培プラン ト（図 1) を実験目的により適宜使用した。均衡培養液 は, $\mathrm{Ca}\left(\mathrm{No}_{3}\right)_{2} \cdot 4 \mathrm{H}_{2} \mathrm{O} ; 1,000 \mathrm{mg} / l, \mathrm{KNO}_{3} ; 850 \mathrm{mg} / l$, $\mathrm{MgSO}_{4} \cdot 7 \mathrm{H}_{2} \mathrm{O} ; 500 \mathrm{mg} / l, \mathrm{NH}_{4} \mathrm{H}_{2} \mathrm{PO}_{4} ; 150 \mathrm{mg} / l$, 市販微 量成分; $10 \mathrm{mg} / l$, 鉄分, EDTA $5 \mathrm{mg} / l$ を 1 単位とし た。

(B) 品 種：トマトの品種は生食用の“瑞秀”, “プチト マト”, “イエローペアトマト”, “レッドペアートマト”, ならびに調理加工用の“ローマ”を使用し（図2），キュ ウリは“北進”を使用した。

(C) 収穫熟度 : キュウリは開花後10日〜14日の収穫適 期で収穫し，トマトは実験目的により，30\%着色果なら びに 100 \%着色果を収穫した。トマトは着果段位が上る につれて，アスコルビン酸含量が多くなると報告されて

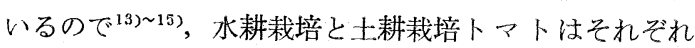
同一般位の果実を供試した。

(2) 官 能 検 査

(A) トマト：個々の果実を花落部からガク部にかけて 6 分割し, 検査に供した。

(B) キュウリ：個々の果実の中央部を $3 \mathrm{~cm}$ の長さに切 り, 検査に供した。

(C) 検査方法：トマトならびにキュウリはそれぞれ，

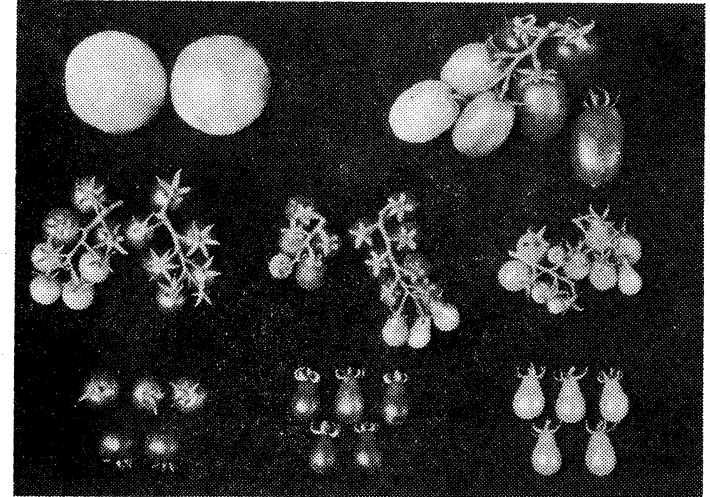

Fig. 2 Tomato fruits grown by hydroponics upper: from left; Zuisyu, Roma lower: from left; Puchi, Red pear, Yellow pear

嗜好試験を行い, 1 回の検査に対して当センターの研究 員 $25 \sim 30$ 人が官能検査員となった。

\section{2. 実 験 結 果}

\section{（1）トマト果実の食味に及ぼす栽培培地の影響}

表 1 は, 土耕栽培トマトと 3 種の培養液濃度で水耕栽 培された果実をそれぞれ比較した官能検查の 結果であ る。硬さについてみると, 培養液濃度が $0.4,0.7$ 単位の 場合は水耕栽培トマトと土耕栽培トマトの間にほとんど 差がなかったが, 1 単位の場合は土耕栽培トマトより水 耕栽培トマトの方が軟かかった。甘さについては，培養 液濃度が 0.4 単位の場合は明らかに土耕栽培卜マトの方 が甘いとされたが， 0.7 単位や 1 単位の場合は差がなか った。

一方, 酸味は培養液濃度が 0.4 単位と 0.7 単位の場合, 土耕栽培と水耕栽培の間に差はみられなかったが，1単 位の場合は, 水耕栽培卜マトの方が酸味が強かった。香 気は, 培養液濃度が 0.4 単位の場合, 明らかに水耕栽培 トマトより土耕栽培トマトの方が強かったが，培養液濃 度を上げるとその差はなくなった。

硬さ, 甘味, 酸味, 香気などを総合的に判断し, どち らの果実を好むかを調べた結果では培養液濃度が 0.4 単 位の場合，水耕栽培トマトを好んだ官能検査員は $17 \%$ で，土耕裁培トマトは $83 \%$ であり，高度に有意な差がみ られたが，培養液濃度を上げると差は小さくなり，1単 位の場合は，ほぼ同数の官能検査員に好まれた。

土耕栽培トマトと水耕栽培トマト（1 単位）の果肉部 ならびにゼリー部の $\mathrm{pH}$ は両測定部位とも栽培培地によ 
Table 1 Effects of Culture medium on hardness, sweetness, acidity, odor, and preference oftomatoes (cv. Zuisyu)

\begin{tabular}{l|ccccc}
\multicolumn{1}{c|}{ Comparison } & Hardness & Sweetness & Acidity & Odor & Preference \\
\hline Soil culture & $54 \% 2$ & $75 \mathrm{~b}$ & 49 & $79 \mathrm{~b}$ & $83 \mathrm{a}$ \\
Hydroponics (0.4 unit) 11 & 46 & 25 & 51 & 21 & 17 \\
\hline Soil culture & 50 & 56 & 53 & 56 & 62 \\
Hydroponics (0.7 unit) & 50 & 44 & 47 & 44 & 38 \\
\hline Soil culture & $74 \mathrm{a}$ & 57 & 33 & 48 & 52 \\
Hydroponics (1 unit) & 26 & 43 & 67 & 52 & 48 \\
\hline
\end{tabular}

※1) Concentrationof culture medium 1 unit; $\mathrm{Ca}\left(\mathrm{NO}_{3}\right)_{2} \cdot 4 \mathrm{H}_{2} \mathrm{O}: 1000 \mathrm{mg}, \mathrm{KNO}_{3}: 850 \mathrm{mg}, \mathrm{MgSO}_{4} \cdot 7 \mathrm{HO}: 500 \mathrm{mg}$, $\mathrm{NH}_{4} \mathrm{H}_{2} \mathrm{PO}_{4}: 150 \mathrm{mg}, \mathrm{B}$. $\mathrm{Zn}$. Fe. : trace, per 1 , respectively

※2) Percentage judged as storonger in hardness, sweetness, acidity, and as preferable. paired comparison test Means : $a-1 \%$ level, $b-5 \%$ level

Table 2 Effects of culture medium on Brix, pH, and titratable acid of tomatoes (cv Zuisyu)

\begin{tabular}{l|l|ccc}
\hline Culture method & & Brix. & $\mathrm{pH}$ & Titratable acid※ \\
\hline \multirow{2}{*}{ Soil culture } & pericarp & 5.6 & 4.3 & 386 \\
& Jelly-like pareachyma & 5.4 & 5.3 & 525 \\
\hline \multirow{2}{*}{ Hydroponics (1 unic) } & pericarp & 6.4 & 4.3 & 436 \\
& Jelly-like parenchyma & 5.8 & 5.5 & 598 \\
\hline
\end{tabular}

※ mg/100g f. wt. as malic acid

Table 3 Effects of culture methods on sweetness, acidity, odor, and preference of $4 \mathrm{cv}$ of tomatoes

\begin{tabular}{l|l|cccc}
\hline \multicolumn{1}{c|}{ cv } & Culture method & Sweetness & Acidity & Odor & Preference \\
\hline \multirow{2}{*}{ Petit } & Soil culture & $48 \%$ & $90 \mathrm{a}$ & $86 \mathrm{a}$ & $76 \mathrm{~b}$ \\
& Hydroponics (0.7 unit) & 52 & 10 & 14 & 24 \\
\hline \multirow{2}{*}{ Yellow Pear } & Soil culture & 66 & 41 & 62 & 55 \\
& Hydroponics (0.7 unit) & 34 & 59 & 38 & 45 \\
\hline \multirow{2}{*}{ Red pear } & Soil culture & $86 \mathrm{~b}$ & 86 & 62 \\
& Hydroponics (0.7 unit) & 14 & 55 & 66 & 38 \\
\hline \multirow{2}{*}{ Roma } & Soil culture & 72 & 45 & 34 & 59 \\
& Hydroponics (0.7 unit) & 28 & & 41 \\
\hline
\end{tabular}

※ Percentage of judge-same as in Table 1 paired comparison test Means : $a-1 \%$ level, $b-5 \%$ level

る差はほとんどみられなかったが，両測定部位の Brix と滴定酸含量は土耕栽培トマトより水耕栽培トマトの方 が高かった（表 2 ）。

水耕栽培を行っている農家は0.5 0.7単位の濃度で栽 培することが多いので, プチトマト, イエローペアトマ ト，レッドペアトマト，ならびにローマの 4 品種を選び 0.7 単位で水耕栽培し, 土耕栽培トマトと食味を比較し た結果は表 3 のよであった。
プチトマトでは差がなかったが，それ以外の 3 品種は 水耕栽培トマトより土耕栽培トマトの方が甘みを強く感 じる官能検査員が多く，とくにレッドペアートマトで は, $84 \%$ の官能検査員が土耕栽培トマトの方を甘く感じ た。酸味はイエローペアートマトとレッドペアートマト は土耕耕培トマトより水耕栽培トマトで強く感じられた が，プチトマトでは反対に，明らかに土耕栽培トマトの 方が酸味が強いと判定された。 
Table 4 Effect of concentration of culture medium of hydroponics on crispness, odor, and preference of cucumber fruits

\begin{tabular}{l|ccc}
\hline & Crispness & Odor & Preference \\
\hline Hydroponics (1 unit) & $64 ※$ & 64 & 70 \\
Hydroponics (2 units) & 36 & 36 & 30 \\
\hline
\end{tabular}

※ Percentage judged as crispness, storonger in odor, and preference paired comparison test

Table 5 Effects of shipping temperature after hardness, sweetness, acidity, dor, and preference of tomatoes (cv Zuisyu) grown by hydroponics (0.7 ucit)

\begin{tabular}{|c|c|c|c|c|c|}
\hline & Hardness & Sweetness & Acidity & Flavo & Liking \\
\hline Fruits I-A & $100 ※ a$ & $19 \mathrm{~b}$ & $18 \mathrm{~b}$ & 43 & 38 \\
\hline Fruits I-B & 0 & 81 & 19 & 57 & 62 \\
\hline Fruits II-A & 89 a & 30 & 70 & 52 & 48 \\
\hline Fruits II-B & 11 & 70 & 30 & 48 & 52 \\
\hline
\end{tabular}

I-A ; 2 days storage at $25^{\circ} \mathrm{C}$, harvested at $30 \%$ coloring $\mathrm{I}-\mathrm{B} ; 2$ days storage at $2^{\circ} \mathrm{C}$, harvested at full ripe II-A ; 4 days storage at $20^{\circ} \mathrm{C}$ harvested at $30 \%$ coloring II-B ; 4 days storage at $2^{\circ} \mathrm{C}$ harvested at full ripe ※ percentage of judge-same as in Table 1

Paired comparison test

Means : $a-1 \%$ level, $b-5 \%$ lbvel

香気は 4 品種とも水耕栽培トマトより土耕栽培トマト の方が強く，プチトマトでは特にその差が大きかった。 その結果, 4 品種とも土耕栽培トマトの方が水耕栽培卜 マトより多くの官能検査員に好まれた。このよらな表 3 の結果は表 1 の 0.7 単位で栽培しだ瑞秀の場合とほぼ同 様であった。

\section{（2）キュウリ果実の食味に及ぼす栽培培地の影響}

キュウリを水耕栽培する場合の培養液濃度を 1 単位と 2 単位として栽培すると，外形はほとんど差はみられな かったが，2 単位で水耕栽培した果実の方が果皮色が濃 く,また果肉の緑色も濃かった。

それぞれのキュウリの官能検査を行うと(表 4)，歯切 れは 1 単位で栽培したキュウリの方が良いとした官能検

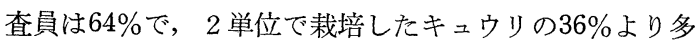
く,香気についても同様の結果であった。その結果, 1 単 位で栽培したキュウリを好む官能検査員は，2 単位で栽 培したキュウリを好む官能検査員の約 2.3 倍であった。

\section{（3）トマト果実の食味に及ぼす追熟温度の影響}

表 5 の果実 I-Aは $30 \%$ 着色で収穫し， $25{ }^{\circ} \mathrm{C}$ で 2 日間
Table 6 Comparison of quality characterstics between tomato fruits (cv Zuisyu, grown by 0.7 unit hydroponics) ripened on the tree and that ripened after harvested at $20^{\circ} \mathrm{C}$

\begin{tabular}{|c|c|c|c|c|c|}
\hline & Hardness & Sweetness & Acidity & Odor & Preference \\
\hline Fruits A & $33 ※$ & 52 & 35 & 39 & 39 \\
\hline Fruits B & 67 & 48 & 65 & 61 & 61 \\
\hline
\end{tabular}

Fruits A; Harvested at $30 \%$ coloring and ripened for 5 days at $20^{\circ} \mathrm{C}$

Fruits B; Harvested at full ripe and tested immediately ※ percentage of judge-same as Table 1 paired comparison test

追熟させた果実で, 果実 I -Bは $100 \%$ 着色で収穫し, $2{ }^{\circ} \mathrm{C}$ で 2 日貯蔵したものを検査時に室温にもどした果実 である。官能検査当日の外観は両者でほとんど差はみら れないが, 食べると, 硬度と酸味は果実 I - A の方が強 く，甘みと香りは果笑 $\mathrm{I}$ 一Bの方が強かった。総合的に 果実 I-A を好んだ官能検査員は38\%であるのに対し, 果実 I-Bは $62 \%$ と明らかに差があり, 流通過程で追熟 させた果実より，完熱したものを収穫し低温流通させた 果実の方が好まれた。

一方，30\%着色果を $20^{\circ} \mathrm{C}$ で追熟させると（果実 II A), 樹上で完熟させ，低温流通させた果実（果実 IIB）との間でも，やはり果実 II-Aの方が硬く，酸味が 強いとした官能検査員は多く, 甘みも果実 II-Bの方が 強かったが，これらの差は果実 $\mathrm{I}$ - $\mathrm{A}$ と果実 $\mathrm{I}$ - $\mathrm{B}$ の差 より小さい傾向があった。香りの強さは，果実 II 一 A と 果実IIーBではほとんど差がなかった。結局 $20^{\circ} \mathrm{C} て ゙$ 追熟 させると，追熟トマトと完熟果を低温流通させたトマト との間に好みに対する有意差はみられなかった。つま り, 流通温度が $25^{\circ} \mathrm{C}$ の場合は, 追熟トマトと完熟させ低 温流通させたトマトの間での食味の差は大きいが，流通 温度が $20^{\circ} \mathrm{C}$ であれば，両者の食味の差は小さくなるよう であった。

しかし，20Cで追熟させても，検査当日に収穫した樹 上完熟トマトと比較すると（表 6 ）甘みの差は小さい が，樹上完熟トマトの方が酸味ならびに香りが強いとし た官能検査員はそれぞれ $65 \%$ と $61 \%$ であり，追熟卜マト より検査当日に収穫された樹上完熟トマトは多くの官能 検查員（61\%）に好まれた。

\section{3. 考察}

一般的に, 水耕栽培で生産された青果物は土耕栽培さ 
れたものに比べ味や香が少ないといわれることが多い。 本研究においても, 培養液温度を低くしてトマトの水耕 栽培を行うと，土耕栽培されたものに比へ，甘味や香気 が少なく,おいしいと感じる官能検査員も少なかったが, 培養液濃度を 1 単位まで高めると，土耕栽培トマトとの 食味の差が小さくなった。その理由として，表 1 の香気 や甘みの項目で，培養液濃度を高めると土耕栽培トマト と水耕栽培トマトの差が小さくなる傾向と，好みの項目 も濃度を上げると，両トマトの間の差が小さくなる傾向 とを合せ考えると, 培養液濃度を高兴水耕栽培トマ トの甘みや香気が増加したため, 土耕栽培トマトとの食 味の差が小さくなったものと思われた。とくに，香気の 増加が食味向上に対して影響が大きいものと思われ DA LAL ら ${ }^{16 \sim 17)}$ や SHAHら ${ }^{18)}$ も香気成分の低下 がトマ 卜の風味の低下に関係が深いとしている。南光ら ${ }^{19)}$ 水 耕栽培と土耕栽培されたトマトの成分を調べた結果にお いて，アスコルビン酸は，水耕の果実に扔いて少し土耕 のものより高い傾向であるが，糖合量は，水耕と土耕の 違いによる差は少ないと報告しており篠原ら ${ }^{11)}$ はトマト で，また青山らはミツバでもあまり両者の差がないと報 告している。このように一般にいわれているほど, 水耕 栽培された青果物の品質は低くないようである。

トマトの水耕栽培の培養液濃度を高めると収穫量が低 下寸るため，0.5 0.7単位の培養液を利用する農家が多 いのであるが，この濃度でトマトを栽培すると，本研究 の供試 5 品種とも, 土耕栽培トマトより甘みや香気が少 なく, 多くの官能検查員には好まれなかった。しかし， 1 単位で栽培すると生産量は低下するものの, 表 2 のよ うに土耕栽培トマトより糖度が高く, 滴定酸含量の高い トマトを栽培できるので, 近年のように量より質を要求 する消費者ニーズに対応して, 現行の培養液濃度を高め る必要があると思われる。

一方キュウリでは培盖液濃度が高いと食味が土耕栽培 のキュウリより低かった。その理由は, 高濃度の培養液 で水耕栽培したキュウリは歯切れが悪く, 香気も青くさ い香が強いためであった。つまり，キュウリはトマトと は異なり, 培養液濃度は低い方が, 食味の良いキュウリ を生産することができた。

つぎに収穫熟度と食味の関係についての報告は多い が21) 28) 青柳ら ${ }^{29)}$ の土耕栽培トマトを使った研究におい て，追熟トマトより樹上完熟トマトの方が食味が良いと されており, 本研究の水耕栽培トマトにおいても同様の
結果が得られた。しかし，本研究においては，樹上完熟 トマトの収穫直後のものに比べると食味は劣るものの, 流通温度を $20^{\circ} \mathrm{C}$ で追熟させると, 樹上で完熟させ低温流 通されたトマトとほぼ同じ香気があり，好みもほとんど 差のないトマトが得られることが明らかとなった。つま り, 追熟温度に留意すれば, 未熟果を収穫してもかな り高品質のトマトを流通させられることが可能と思われ る。

近年のトマトの食味に関する問題点は, 栽培培地を改 良し, より樹上で熟したものを収穫し, 追熟温度を今よ り低くすることによってある程度は解決できるものと思 われる。

\section{4. 摘 要}

本研究は, 生食用キュウリと生食ならびに調理・加工 用トマトの品質に及ぼす栽培培地の影響を調べるととも に, 流通温度がトマトの食味に及ぼす影響を調べたもの である。

(1) トマトの水耕栽培培養液の濃度を $0.4,0.7$ および 1 単位として栽培すると濃度の高いほど食味がよくなる 傾向があり，1 単位で栽培すると土耕栽培トマトとほぼ 同様の食味となった。1 単位の培養液濃度で栽培された トマトの $\mathrm{pH}, \mathrm{Brix}$, 滴定酸含量は土耕栽培トマトとほぼ 同様であった。

(2) 0.7 単位の培養液で水耕栽培した調理・加工用なら びに生食用トマト 5 品種は, 品種により多少異なるが, 土耕栽培トマトの方が多くの官能検査員に好まれた。

(3)キュウリは培養液濃度を 1 単位から 2 単位に上げ ると歯切れが覀くなり, 食味が低下した。

(4) $30 \%$ 着色で収穫し $20^{\circ} \mathrm{C}$ で 4 日追熟させたトマトの 食味は，100％％着色で収穫し冷蔵したトマトとほぼ同 じであった。しかし, 追熟トマトの食味は検査当日収穫 された樹上完熟トマトより悪かった。

\section{参考文献}

1) 篠原 温ら : 園学雑, 47, 63 70 (1978)

2) 山内直樹ら : 栄養と食糧, 33, 293 298 (1980)

3) 篠原 温ら : 園学雑, 49, 85 92 (1980)

4) 篠原温ら: 園学雑, 50, 239 246 (1981)

5) 吉田企世子ら : 日本栄養・食糧学会誌, 37, 115 121（19 84)

6）吉田企世子ら：日本栄養・食糧学会誌, 37, 123 127（123 $\sim 127$ (1984)

7) 吉田企世子ら : 日本栄養・食糧学会誌，37，267 272（19 84) 
8）鯨 幸夫：日本栄養・食糧会誌，37，239 244（1984）

9）鯨 幸夫：日本栄養・食糧会誌, 37, 245 250 (1984)

10）高間総子ら：コールドチェーン研究，2，60６4 (1976)

11）青山文雄ら：栄盖と食糧，31，355 359（1978）

12）阿部一博：日本コールトチェン研究発表要旨, 14 (1983)

13) FRYER, H. C. et al: Proc. Amer. Soc. Hort. Sci., 64, 360 364 (1954)

14）木下隆雄ら：野菜試研究年報, 149 154（1976）

15) McCOllum, J. P. et al : Proc. Amer. Soc. Hort. Sci., 45, 382 386 (1944)

16) DALAK, K. B. et al : Phytochem, 6, 155 157 (19 67)

17) DALAL, K. B. et al : Plant and Cell Physiol. 9, 389 400 (1968)

18) SHAH, B. M. et al: J. Amer. Soc. Hort. Sci, 94, $171 \sim 176$ (1969)
19）南光美子ら：園芸学研究集録, 9, 66 70 (1979)

20) 篠原 温ら：園学雑, 51, 338 343 (1982)

21) BELANCOURT, L. A. et al : J. Amer. Soc. Hort. Sci., 102, 721 723 (1977)

22) BISOGNI, C. A. et al: J. Food Sci., 41, 333 338 (1976)

23) 万豆剛一ら：農及園, 41，355 356 (1966)

24) KADER. A. A. et al : J. Amer. Soc. Hort. Sci., 102, 724 731 (1977)

25) KADER, A. A. et al: J. Amer. Soc. Hort. Sci., 103, 6 13 (1978)

26) KADER, A. A. et al: J. Amer. Soc. Hort. Sci., 103, $541 \sim 544$ (1978)

27）緒方邦安ら : 香川農大学報, 2, 121 129 (1951)

28）大久保増太郎ら：千葉農試研報， 6, 181 190 (1965)

29）青柳光昭ら：園芸学会発表要旨，438４39（1978） 